\title{
HUBUNGAN PENGETAHUAN DAN PENDAPATAN ORANGTUA DENGAN TERJADINYA PERNIKAHAN USIA DINI DI DESA JANJIMAULI MUARATAIS III KECAMATAN ANGKOLA MUARATAIS TAHUN 2019
}

\author{
Lisna Khairani Nasution \\ STIKes Darmais Padangsidimpuan \\ *Lisna Khairani Nasution: Jl. Belibis Perumahan Sopo Indah Kecamatan \\ Padangsidimpuan Tenggara, Indonesia, \\ E-mail:lisnakhairaninasution.09@gmail.com Phone: +6281362712302
}

\begin{abstract}
ABSTRAK
Pernikahan usia dini menurut BKKBN adalah pernikahan yang di lakukan pada usia remaja (dibawah 21 tahun pada wanita dan di bawah 25 tahun pada pria). Berdasarkan data BPS Provinsi Sumatera Utara berdasarkan di pedesaan dan di perkotaan. Persentase Wanita $\geq$ 15-18 Tahun. Pernikahan usia dini di Perdesaan umur $\leq 15$ Tahun sebanyak 3.81\% dan 1618 Tahun 23.69\%. Selanjutnya, Pernikahan usia dini di perkotaan $\leq 15$ Tahun 2.22\% dan 1618 Tahun 16.55\% (BPS, 2015). Menurut data Kantor Urusan Agama Kec.Angkola muaratais tahun 2017, tercatat jumlah pernikahan remaja yang menikah di bawah usia 21 tahun sebanyak 40 orang $(61.2 \%)$, rata-rata menikah setelah lulus SMP dan sebelum lulus SMA. Tujuan penelitian untuk mengetahui hubungan pengetahuan dan pendapatan orangtua dengan terjadinya pernikahan usia dini di desa Janjimauli Muaratais III Kec. Angkola Muaratais tahun 2019.Jenis penelitian survey dengan menggunakan desain cross sectional. Sampel dalam penelitian ini berjumlah 40 responden. Instrumen yang digunakan yaitu kuesioner. Analisis data dilakukan secara univariat dan bivariat dengan uji chi-square $(\alpha=0,05)$. Hasil penelitian didapatkan bahwa faktor yang berhubungan dengan terjadinya pernikahan usia dini adalah faktor pengetahuan ( $p$-value=0,008), dan pendapatan orangtua (p-value=0,037). Jadi variabel pengetahuan dan pendapatan orangtua memiliki hubungan dengan terjdinya pernikahan dini di desa janjimauli Muaratais III Kec. Angkola Muaratais Tahun 2019.
\end{abstract}

Kata kunci: Pengetahuan, pendapatan orangtua, pernikahan dini 


\begin{abstract}
ABSTRAC
According to the BKKBN, early marriage is marriage that is carried out at a young age (under 21 years for women and under 25 years for men). Based on BPS data from the Province of North Sumatra, based on rural and urban areas. Percentage of Women 15-18 Years. Early marriage in rural areas aged 15 years is $3.81 \%$ and $16-18$ years is $23.69 \%$. Furthermore, early marriage in urban areas 15 years is $2.22 \%$ and $16-18$ years is $16.55 \%$ (BPS, 2015). According to data from the Office of Religious Affairs in Angkola Muaratais in 2017, there were 40 married youths who were married under the age of 21 (61.2\%), on average after graduating from junior high school and before graduating from high school. The purpose of this study was to determine the relationship between knowledge and parental income with the occurrence of early marriage in the village of Promise Muaratais III, Kec. Angkola Muaratais in 2019. This type of survey research uses a cross sectional design. The sample in this study amounted to 40 respondents. The instrument used is a questionnaire. Data analysis was carried out univariate and bivariate with chi-square test $(\alpha=0.05)$. The results showed that the factors associated with the occurrence of early marriage were knowledge $(p$-value $=0.008)$, and parental income $(p$-value $) .=0.037)$. So, the variables of knowledge and parental income have a relationship with the occurrence of early marriage in the village of Janjimauli Muaratais III, Kec. Angkola Muaratais in 2019.
\end{abstract}

Keywords: Knowledge, parent's income, Early Childhood Marriage

\title{
Pendahuluan
}

Pernikahan adalah status terikat dalam pernikahan, baik tinggal bersama maupun terpisah (kawin sah, secara hukum/adat, agama, negara dan sebagainya, juga hidup bersama dan oleh masyarakat sekelilingnya dianggap sebagai suami istri (BPS, 2015). Menurut Badan Koordinasi Keluarga Berencana Nasional (BKKBN), usia pernikahan yang ideal yang dilakukan oleh seorang laki-laki dengan usia minimal 25 tahun dan usia minimal wanita 21 tahun. Namun pada kenyataanya masih begitu banyak masyarakat yang melakukan pernikahan pada usia dibawah 18 tahun (BKKBN, 2017).

Organisasi kesehatan dunia (WHO) tahun 2012 menunjukkan bahwa sebanyak 16 juta kelahiran terjadi pada ibu yang berusia 15-19 tahun atau 11\% dari seluruh kelahiran di dunia yang mayoritas $95 \%$ terjadi di negara sedang berkembang. Di Amerika Latin dan Karibia, 29\% wanita muda menikah saat mereka berusia 18 tahun. Prevalensi tertinggi kasus pernikahan usia dini tercatat di Nigeria (79\%), Kongo (74\%), Afganistan (54\%), dan Bangladesh (51\%) (WHO, 2012). Menurut WHO (World Health Organization) batasan usia muda adalah 11-20 tahun. Di Afrika Sub-Sahara dan Amerika Latin, 60\% wanita tanpa pendidikan dasar menikah sebelum usia 18 tahun. Perbedaan ini juga tampak di Negara- 
negara maju seperti AS, 30\% dari wanita yang menempuh pendidikan kurang dari 10 tahun akan menikah sebelum usia 18 tahun. Hal ini berbeda dengan wanita yang menempuh pendidikan lebih dari 10 tahun menikah di usia sebelum 18 tahun terjadi kurang dari 10\% (WHO, 2012).

Faktanya berdasarkan data dari Riset Kesehatan Dasar (Riskesdas) tahun 2010, menunjukan masih tingginya kejadian pernikahan usia anak di Indonesia yaitu perempuan dengan usia 10-14 tahun menikah sebanyak 0,2\% lebih dari 22.0000 wanita muda berusia 10-14 tahun di Indonesia yang sudah menikah. Jumlah perempuan muda yang menikah lebih besar jika dibandingkan dengan laki-laki yaitu $11,7 \%$ perempuan muda berusia 15-19 tahun dan 6\% laki-laki berusia 15-19 (Riskesdas, 2010).

Berdasarkan data Pendataan Keluarga tahun 2014. Provinsi Sumatera Utara tahun 2014 jumlah PUS (Pasangan Usia Subur) dengan usia istri dibawah 20 tahun sebanyak 75512 orang (Pendataan Keluarga, 2014 dalam Rahayu, 2016). Data BPS Provinsi Sumatera Utara berdasarkan di pedesaan dan di perkotaan. Persentase Wanita $\geq 15-18$ Tahun. Pernikahan usia dini di Perdesaan umur $\leq 15$ Tahun sebanyak 3.81\% dan 16-18 Tahun 23.69\%. Selanjutnya, Pernikahan usia dini di perkotaan $\leq 15$ Tahun $2.22 \%$ dan $16-18$ Tahun $16.55 \%$ (BPS, 2015).

Penyebab terjadinya pernikahan usia dini tergantung pada kondisi dan kehidupan sosial masyarakatnya. Terdapat dua alasan utama terjadinya pernikahan dini, pertama, pernikahan usia dini sebagai strategi untuk bertahan secara ekonomi. Kemiskinan adalah salah satu faktor utama yang menjadi tiang pondasi munculnya pernikahan dini. Pernikahan usia dini meningkat ketika tingkat kemiskinan juga meningkat. Penyebab kedua adalah untuk melindungi anak gadisnya. Pernikahan adalah salah satu cara untuk memastikan anak perempuan mereka terlindungi sebagai istri, melahirkan anak yang sah dimata hukum dan akan lebih aman jika memiliki suami yang dapat menjaga mereka secara teratur (UNICEF, 2005).

Pendidikan orang tua juga memiliki peranan dalam keputusan buat anaknya, karena di dalam lingkungan keluarga ini, pendidikan anak yang pertama dan utama (Nandang, 2009). Juspin (2012). Mengemukakan bahwa peran orang tua terhadap kelangsungan pernikahan usia dini pada dasarnya tidak terlepas dari tingkat pengetahuan orang tua yang dihubungkan pula dengan tingkat pendidikan orangtua, salah satu faktor yang dapat mempengaruhi keputusan orang tua terhadap anaknya salah satunya yang menonjol adalah pendidikan keluarga. Selain itu faktor yang berhubungan adalah pekerjaan pelaku pernikahan dini. 
Pekerjaan dapat mengukur status sosial ekonomi serta masalah kesehatan dan kondisi tempat seseorang bekerja (Guttmacher dalam yunita 2014) dan hal ini sesuai juga dengan penelitian Zai (2010) yang mengungkapkan bahwa terdapat hubungan antara pekerjaan responden dengan kejadian pernikahan dini, pekerjaan seseorang dapat mencerminkan pendapatan, status sosial, pendidikan dan masalah kesehatan bagi orang itu sendiri. Penyebab dari pernikahan dini di Indonesia dipengaruhi oleh banyak faktor, antara lain pendidikan rendah, kebutuhan ekonomi, kultur nikah muda, seks bebas pada remaja dan pemahaman agama (BKKBN, 2011). Pernikahan dilingkungan remaja cenderung berdampak negatif baik dari segi sosial ekonomi, mental/psikologis, fisik terutama kesehatan reproduksi remaja tersebut (Nad, 2014).

Menurut data Kantor Urusan Agama Kecamatan Angkola muaratais tahun 2017, tercatat jumlah pernikahan remaja yang menikah di bawah usia 21 tahun sebanyak 40 orang terdapat 61,6\% dari 62 orang remaja, rata-rata menikah setelah lulus SMP dan sebelum lulus SMA. Berdasarkan data dari Kantor Kepala Desa Tahun 2018, pernikahan usia dini di Desa Janjimauli Muaratais III dengan jumlah perempuan dan laki-laki yang menikah di usia 14-20 tahun sebanyak 40 dan sudah tercacat di kantor urusan agama Kecamatan Angkola Muaratais.

Berdasarkan hasil survei pendahuluan yang telah dilakukan didapatkan data melalui wawancara terhadap 10 remaja yang menikah usia dini, 2 orang mengatakan karena melihat teman sebaya sudah banyak yang menikah, 2 orang mengatakan karena menganggap setelah menikah akan mengurangi beban orang tua dari segi ekonomi keluarga karena pendapatan orangtua hanya pas pasan, 3 orang mengatakan karena sudah hamil diluar nikah, 3 orang mengatakan daripada berdosa lebih baik menikah saja kan tidak ada lagi larangan. Selain itu dari survei awal tersebut 7 dari 10 responden mengalami kehamilan dan persalinan di usia yang masih sangat muda, 2 orang diantaranya mengalami keguguran, 2 orang diantaranya mengalami pertumbuhan anak yang terlambat karena tidak tau mengolah makanan untuk bayinya, 2 orang mengalami perdarahan postpartum, 1 orang mengalami postpartum blues.

Berdasarkan latar belakang tersebut diatas, peneliti tertarik melakukan penelitian tentang "faktor-faktor yang berhubungan dengan terjadinya pernikahan usia dini di Desa Janjimauli Muaratais III Kecamatan Angkola Muaratais Tahun 2019”.

\section{Metode}

Penelitian ini merupakan penelitian survei dengan tipe cross sectional. Desain penelitian yang digunakan adalah cross sectional merupakan penelitan dimana pengukuran atau pengamatan dilakukan pada saat bersamaan pada data variabel independen dan dependen (sekali sewaktu). 
Populasi dalam penelitian ini yaitu remaja laki-laki dan perempuan di Desa Janjimauli Muaratais III Kecamatan Angkola Muaratais Tahun 2019 sebanyak 40 orang. Tehnik pengambilan sampel yang digunakan dalam penelitian ini adalah total sampling. Jadi sampel penelitian ini berjumlah 40 orang remaja laki-laki dan perempuan.

\section{Hasil}

Tabel 1 . Distribusi Frekuensi Berdasarkan Pengetahuan Responden di Desa Janjimauli Muaratais III Kecamatan Angkola Muaratais

\begin{tabular}{clcc}
\hline No & Pengetahuan & Jumlah & Persentase (\%) \\
\hline 1 & Kurang baik & 34 & $85.0 \%$ \\
2 & Baik & 6 & $15.0 \%$ \\
\hline & Total & 40 & $100 \%$ \\
\hline
\end{tabular}

Tabel 2 : Distribusi Frekuensi Berdasarkan Pendapatan Orangtua Responden di Desa Janjimauli Muaratais III Kecamatan Angkola Muaratais

\begin{tabular}{clcc}
\hline No & Pendapatan Orangtua & Jumlah & Persentase\% \\
\hline 1 & Rendah & 33 & $82.5 \%$ \\
2 & Tinggi & 7 & $17.5 \%$ \\
\hline & Total & 40 & $100.0 \%$ \\
\hline
\end{tabular}

\section{Analisis Bivariat}

Analisis bivariat ini dilakukan untuk mengetahui hubungan Pengetahuan dan pendapatan Orangtua dengan terjadinya pernikahan dini di Desa Janjimauli Muaratais III Kecamatan Angkola Muaratais dengan menggunakan uji statistic Chi-square pada tingkat derajat kepercayaan $95 \%$ dan batas kemaknaan $\mathrm{P}<0,05$.

Tabel 3 : Distribusi berdasarkan hubungan pengetahuan dengan terjadinya pernikahan dini di Desa Janjimauli Muaratais III Kecamatan Angkola Muaratais

\begin{tabular}{|c|c|c|c|c|c|c|c|}
\hline \multirow{3}{*}{ Variabel } & \multicolumn{4}{|c|}{ Pernikahan } & \multirow{2}{*}{\multicolumn{2}{|c|}{ Total }} & \multirow{3}{*}{ Nilai P } \\
\hline & \multicolumn{2}{|c|}{ Menikah } & \multicolumn{2}{|c|}{$\begin{array}{c}\text { Tidak } \\
\text { Menikah } \\
\end{array}$} & & & \\
\hline & $\mathbf{N}$ & $\%$ & $\mathbf{n}$ & $\%$ & $\mathbf{N}$ & $\%$ & \\
\hline \multicolumn{8}{|l|}{ Pengetahuan } \\
\hline Baik & 6 & 15 & 0 & 0 & 6 & 15 & 0.008 \\
\hline Kurang Baik & 14 & 35 & 20 & 50 & 34 & 85 & \\
\hline Total & 20 & 50 & 20 & 50 & 40 & 100 & \\
\hline
\end{tabular}

Tabel 4 : Distribusi berdasarkan hubungan Pendapatan Orangtua dengan terjadinya pernikahan dini di Desa Janjimauli Muaratais III Kecamatan Angkola Muaratais 


\begin{tabular}{|c|c|c|c|c|c|c|c|}
\hline \multirow{3}{*}{ Variabel } & \multicolumn{4}{|c|}{ Pernikahan } & \multirow{2}{*}{\multicolumn{2}{|c|}{ Total }} & \multirow{3}{*}{ Nilai $\mathbf{P}$} \\
\hline & \multicolumn{2}{|c|}{ Menikah } & \multicolumn{2}{|c|}{$\begin{array}{c}\text { Tidak } \\
\text { Menikah }\end{array}$} & & & \\
\hline & $\mathbf{N}$ & $\%$ & $\mathbf{n}$ & $\%$ & $\mathbf{N}$ & $\%$ & \\
\hline \multicolumn{8}{|c|}{ Pendapatan Orangtua } \\
\hline Baik & 19 & 47.5 & 14 & 35 & 33 & 82.5 & \\
\hline Kurang Baik & 1 & 2.5 & 6 & 15 & 7 & 17.5 & 0.037 \\
\hline Total & 20 & 50 & 20 & 50 & 40 & 100 & \\
\hline
\end{tabular}

\section{Pembahasan}

Berdasarkan hasil penelitian berdasarkan Pendidikan orangtua responden adalah menikah dengan pendidikan dasar sebanyak 16 orang (40\%) dan pendidikan lanjut sebanyak 4 orang $(10 \%)$. Sedangkan responden tidak menikah adalah pendidikan dasar sebanyak 16 orang (40\%) dan pendidikan lanjut sebanyak 4 orang (10\%) dan berdasarkan Pendapatan orangtua adalah menikah dengan berpendapatan rendah sebanyak 19 (47.5\%), berpendapatan tinggi sebanyak 1 orang (2.5\%). Sedangkan responden tidak menikah berpendapatan rendah sebanyak 14 orang (35\%), berpendapatan tinggi seanyak 6 orang (15\%).

Hasil analisis diperoleh hubungan pengetahuan responden dengan pernikahan usia dini adalah yaitu menikah dengan berpengetahuan baik sebanyak 6 orang (15\%) dan berpengetahuan kurang baik sebanyak 14 orang (35\%). Sedangkan responden tidak menikah adalah berpengetahuan baik sebanyak 0 orang $(0.0 \%)$ dan berpengetahuan kurang baik sebanyak 20 orang $(50,0 \%)$.

Hasil analisis Chi Square menunjukan bahwa nilai $p$ value 0,008 (p<0,05) artinya Ha diterima dan $\mathrm{H} 0$ ditolak. Hasil tersebut membuktikan bahwa terdapat hubungan yang signifikan antara pengetahuan dengan Pernikahan Usia Dini di Desa Janjimauli Muaratais III Kecamatan Angkola muaratais tahun 2019.

Hasil analisis diperoleh hubungan pendapatan orangtua dengan pernikahan usia dini adalah paling banyak pada kategori berpendapatan rendah sebanyak 33 orang (82.5\%) dan paling sedikit pada kategori berdapatan tinggi sebanyak 7 orang $(17.5 \%)$.

Hasil analisis Chi Square menunjukan bahwa nilai $p$ value 0,037 (p<0,05) artinya Ha diterima dan $\mathrm{HO}$ ditolak. Hasil tersebut membuktikan bahwa terdapat hubungan yang signifikan antara pendapatan orangtua dengan Pernikahan Usia Dini di Desa Janjimauli Muaratais III Kec.Angkola muaratais tahun 2019.

Tingginya angka pernikahan dini akan memiliki dampak yang banyak terhadap kesehatan mulai dari kesehatan ibu antara lain belum siapnya organ reproduksi ibu sehingga 
menimbulkan terjadinya kehamilan premature, keguguran hingga perdarahan akibat faktor psikologis ibu yang belum siap sehingga yang dapat menyebabkan kematian pada ibu sedangkan dampak untuk anak terjadinya kelahiran premature, kurang asupan gizi yang sangat fatal akibatnya untuk kesehatan anak. Oleh kaena itu remaja harus memiliki pengetahuan mengenai pentingnya kesehatan reproduksi dan mendapatkan pendidikan kesehatan reproduksi yang benar dan layak dari sumber yang terpercaya. Perlu peran pemerintah untuk memberikan edukasi tentang kesehatan reproduksi dan kegiatan-kegiatan yang positif untuk menghindari pernikahan dini. Edukaski tersebut khususnya untuk masyarakat di daerah yang memiliki angka pernikahan dini yang cukup tinggi.

\section{Kesimpulan}

Berdasarkan hasil penelitian dan pembahasan yang telah dilakukan dapatdiambil kesimpulan sebagai berikut :

1. Ada hubungan pengetahuan responden dengan terjadinya pernikahan usia dini di Desa Janjimauli Muaratais III Kecamatan Angkola Muaratais

2. Ada hubungan pendapatan orangtua responden dengan terjadinya pernikahan usia dini di Desa Janjimauli Muaratais III Kecamatan Angkola Muaratais

\section{Referensi}

1. Badan Koordinasi Keluarga Berencana Nasional, 2018, Pencegahan Pernikahan Anak melalui Program KKBPK, Banjarmasin

2. Badan Koordinasi Keluarga Berencana Nasional, 2017, Usia Pernikahan Ideal 21-25 Tahun, Samarinda

3. Badan Koordinasi Keluarga Berencana Nasional, 2012, Survei Demografi dan Kesehatan Indonesia : Jakarta

4. BKKBN, 2011. Profil Hasil Pendataan Keluarga Tahun 2011. Jakarta: Badan Kependudukan dan Keluarga Berencana Nasional Direktorat Pelaporan dan Statistik.

5. BPS. 2015. Data Statistik tentang Perkawinan di Indonesia. Terbitkan oleh direktur statistika kependudukan Ketenagakerjaan BPS RI. Jakarta

6. Buletin penelitian sistem kesehatan (Bulletin Of Health system research), Vol. 23 no.4 2021

7. Dachlan, T, 2016, Faktor-Faktor Remaja Memilih Menikah Pada Usia Dini. Skripsi. Fakultas Psikologi Universitas Muhammadiyah Malang

8. Desiyanti, Irne W, 2015. Faktor-Faktor yang Berhubungan Terhadap Pernikahan Dini Pada Pasangan Usia Subur di Kecamatan Mapanget . Skripsi. Manado

9. Kementrian Kesehatan RI, 2011, Pusat Komunikasi Publik, Sekretariat Jenderal Kementerian Kesehatan RI. Jakarta

10. Nad, 2014 Remaja dan status Sosial Ekonomi,Jakarta

11. Noatmodjo, 2013, Metodologi Penelitian Kesehatan,Rineka Cipta : Jakarta 
12. Noatmodjo, 2013, Ilmu Kesehatan Masyarakat Prinsip-Prinsip Dasar. Rineka Cipta: Jakarta

13. Noatmodjo, 2013, Pendidikan dan Perilaku Kesehatan. Rineka Cipta : Jakarta

14. Nurkhasanah, U. 2012. Perkawinan Usai Muda dan Perceraian Di Kampung Kotabaru Kecamatan Padang Ratu Kabupaten Lampung Tengah. Jurnal Sosiologi. Universitas Lampung. Bandar Lampung.

15. Purwandari. A. 2011. Ilmu Kesehatan Masyarakat dalam Konteks Kebidanan. Penerbit Buku Kedokteran EGC : Jakarta

16. Purwaningsih Endah, Setyaningsih Tri Ria , 2014, Hubungan Pola Asuh Orangtua dengan Kejadian Pernikahan Usia Dini di Desa Jambu Kidul, Ceper, Klaten

17. Purba, M.B.A, 2017, Faktor-Faktor Yang Berhubungan Dengan Pernikahan Dini Di Dusun I Desa Baru Kecamatan Pancur Batu Kabupaten Deli Serdang. Tesis. Universitas Sumatera Utara

18. Rahayu, 2016, Pengaruh Komunikasi Keluarga Terhadap Sikap Remaja Dalam Menanggapi Pernikahan Dini Di Desa Mabar, Kecamatan Bangun Purba. Skripsi. Universitas Sumatera Utara

19. Rahardjo sumardi dan Riyanti imron, 2013. Determinan Pernikahan Dini diKecamatan Kalianda, volume IV, nomor 2, 2013, hlm 357-363. Diakses 24 juni 2019

20. Romauli, 2012, Kesehatn Reproduksi. Nuha Medika : Yogyakarta

21. Salamah, S, 2016, Faktor-Faktor Yang Berhubungan Dengan Pernikahan Usia Dini Di Kecamatan Pulokulon Kabupaten Grobogan. Skripsi. Universitas Negeri Semarang

22. Suparmi, 2017, Kesehatan Reproduksi Berbasis Kompetensi, di Terbitkan oleh Buku Kedokteran EGC: Jakarta

23. Yunita, A. 2014. Faktor-Faktor yang Berhubungan dengan kejadian pernikahan usia muda pada remaja putri di desa pagerejo Kabupaten Wonosobo, Skripsi. Wonosobo Ngudi Waluyo

24. Wulandari dan Sarwoprasodjo Sarwititi, 2014. Pengaruh Ekonomi Keluarga Terhadap Motif Menikah Dini di Perdesaan. 